\title{
Selective Carboxylation of Benzoic Acid Using Cyclodextrin as Mediator
}

\author{
Yukihide Shiraishi, Shin-ichi KoJima, Hirofumi Tomita, Harunobu Ohsuka, \\ Tokiji Kawamura, ${ }^{*}$ Naoki Toshima, ${ }^{*}$ and Hidefumi HiraI ${ }^{\dagger}$ Kagurazaka, Shinjuku-ku, Tokyo 162, Japan
* Department of Applied Chemistry, Faculty of Engineering, The University of Tokyo, Hongo, Bunkyo-ku, Tokyo 113, Japan \\ Department of Industrial Chemistry, Faculty of Engineering, Science University of Tokyo,
}

(Received January 16, 1996)

\begin{abstract}
The selective synthesis of terephthalic acid from benzoic acid with carbon tetrachloride, copper powder, and aqueous alkali was achieved by the use of $\beta$-cyclodextrin $\left(\beta\right.$-CyD) as a mediator at $60^{\circ} \mathrm{C}$ under nitrogen of atmospheric pressure, producing terephthalic acid in $74 \mathrm{~mol} \%$ yield with $100 \%$ selectivity. When $\alpha$-CyD or $\gamma$-CyD was used instead of $\beta$ - $\mathrm{CyD}$, the reaction hardly proceeded. The addition of $p$-benzoquinone to the reaction mixture decreased the yield of terephthalic acid remarkably. An oxygen atmosphere also suppressed the reaction appreciably. Thus, the active species formed from carbon tetrachloride and copper powder in the reaction mixture is proposed to be trichloromethyl radical. The conformations of CyDbenzoate inclusion complexes in aqueous alkaline solution were determined by the nuclear magnetic resonance spectroscopy using ${ }^{1} \mathrm{H}$ homonuclear Overhauser enhancement on the rotating frame. The benzoate anion was axially included in the cavity of $\beta$-CyD with orientation such that the carboxylate group was at the primary hydroxyl side of $\beta$-CyD. The essential factor of the carboxylation by the use of $\beta-\mathrm{CyD}$ was the inclusion complex formation of $\beta$-CyD with benzoate anion and $\beta$-CyD with carbon tetrachloride in the reaction mixture. The very high selectivity was ascribed to the conformation of the $\beta$-CyD-benzoate inclusion complex.

KEY WORDS Carboxylation, Benzoic Acid / Inclusion Complex, $\beta$-Cyclodextrin-Benzoate / Radical Inhibitor / Formation Constant / Conformation, Inclusion Complex / Nuclear Magnetic Resonance, ${ }^{1} \mathrm{H} /$ Rotating Frame Overhauser Enhancement Spectroscopy /
\end{abstract}

Terephthalic acid is widely used as an essential monomer, not only for conventional polyesters, namely poly(ethylene terephthalate) and poly( $p$-phenylene terephthalamide), but also for high performance polymers such as poly[(terephthalic acid)-alt-( $p$-phenylene diamine; $3,4^{\prime}$-diaminodiphenylether)], poly( $p$-phenylene benzobisthiazol), etc. Usually, terephthalic acid is produced by liquid-phase oxidation of $p$-xylene, ${ }^{1}$ and by disproportionation of potassium benzoate. ${ }^{2}$

Alpha-, $\beta$-, and $\gamma$-cyclodextrins $(\alpha-\mathrm{CyD}, \beta$-CyD, and $\gamma$-CyD) are cyclic oligomers of 6,7 , and 8 glucose units, respectively, as shown in Figure 1, and form inclusion complexes with aromatic compounds in aqueous solution. ${ }^{3,4}$

Reimer and Tiemann ${ }^{5}$ reported the syntheses of 2hydroxybenzoic acid and 4-hydroxybenzoic acid from phenol and carbon tetrachloride without copper powder in aqueous alkali. The yields of hydroxybenzoic acids were very low. Komiyama and Hirai ${ }^{6}$ reported that the

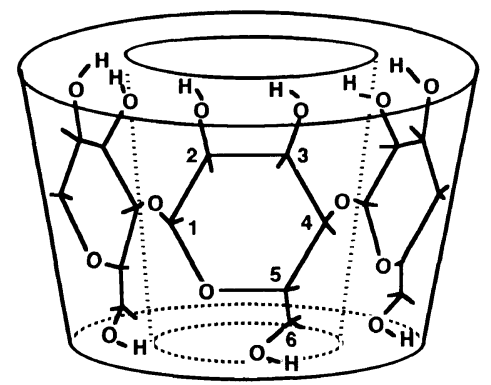

$\beta$-CyD

Figure 1. Structure and positional numbers of protons in $\beta$-CyD. reaction of phenol with carbon tetrachloride and copper powder in aqueous alkali using $\beta$-CyD as mediator produced 4-hydroxybenzoic acid in $59 \mathrm{~mol} \%$ yield with $99 \%$ selectivity. The hydroxyl group of phenol has activating effect on the electrophilic substitution reaction of the aromatic ring. ${ }^{7}$ The carboxyl group of benzoic acid has deactivating effect. ${ }^{7}$ For example, the yield of 2-hydroxybenzaldehyde was $35 \mathrm{~mol} \%$ on the formylation of phenol, whereas that of 5-formyl-2-hydroxybenzoic acid was $17 \mathrm{~mol} \%$ on the formylation 2hydroxybenzoic acid. ${ }^{8}$ These low yields were due to the deactivating effect of the carboxyl group. ${ }^{8}$ Consequently, the electrophilic substitution reaction of benzoic acid should occur slightly at the meta position. In previous communications, we reported preliminarily the selective carboxylation of benzoic acid using $\beta$-CyD as mediator, ${ }^{9}$ and the conformation of the $\beta$-CyD-benzoate inclusion complex. ${ }^{10}$

This paper describes detailed results of the selective synthesis of terephthalic acid from benzoic acid, carbon tetrachloride and copper powder in aqueous sodium hydroxide solution under mild conditions by the use of $\beta$-CyD as mediator, as shown in Scheme 1. The active species formed from carbon tetrachloride and copper powder is examined by using radical inhibitors. The conformations of $\beta$-CyD-benzoate inclusion complex ${ }^{10}$

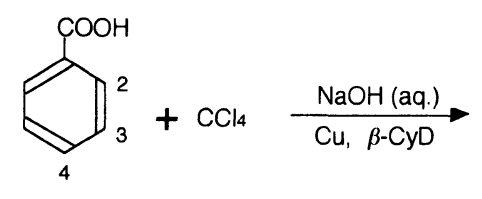

Benzoic acid

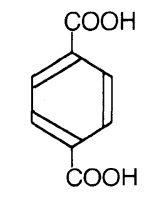

Terephthalic acid

Scheme 1. 
and $\alpha$-CyD-benzoate inclusion complex in aqueous alkaline solution were determined by the rotating frame Overhauser enhancement spectroscopy (ROESY). ${ }^{1-13}$ The positional selectivity of the carboxylation is discussed on the basis of the conformation of the inclusion complex.

\section{EXPERIMENTAL}

\section{Materials}

beta-Cyclodextrin $(\beta$-CyD) was purchased from Tokyo Chemical Industry Co. and recrystallized from aqueous solution. alpha- and $\gamma$-CyD were obtained from Nacalai Tesque Inc. and recrystallized from aqueous solution. Copper powder was used of organic synthesis grade (the average diameter of particles $1 \mu \mathrm{m}$ ) from Aldrich Chemical Co. Benzoic acid was obtained from Kanto Chemical Co. and recrystallized from aqueous solution. para-Benzoquinone was purified by sublimation. All other chemicals were purified by the usual ways.

\section{Carboxylation}

Three mmol of benzoic acid, $0.8 \mathrm{mmol}(0.05 \mathrm{~g})$ of copper powder, and $3.0 \mathrm{mmol}$ of $\beta$-CyD were added to $30 \mathrm{~mL} 30 \mathrm{wt} \%$ aqueous sodium hydroxide solution. The reaction was started with the addition of $9.5 \mathrm{mmol}$ of carbon tetrachloride and continued for $7 \mathrm{~h}$ at $60^{\circ} \mathrm{C}$ under nitrogen. Then, residual carbon tetrachloride was removed by evaporation under reduced pressure. The cooled reaction mixture was neutralized with hydrochloric acid. The $\mathrm{pH}$ value of the mixture was adjusted to 9.7 with an aqueous sodium hydroxide solution, followed by filtration of the mixture through a sintered glass disk. The filtrate was analyzed by high performance liquid chromatography (HPLC) using absorbance at $254 \mathrm{~nm}$. The main product was isolated and confirmed to be terephthalic acid by comparison with authentic samples (HPLC, IR, MS, ${ }^{1} \mathrm{H}$-NMR). The yield of terephthalic acid and recovery of benzoic acid were based on the starting amount of benzoic acid. The selectivity of terephthalic acid was based on the total amount of carboxylated products.

Determination of Inclusion-Complex Formation Constant Inclusion-complex formation constants were determined by the Benesi-Hildebrand method, ${ }^{14,15}$ as follows. $X$ and $Y$ are the initial concentrations of $\beta$-CyD and substrate, having molar extinction coefficients of $\varepsilon_{\mathrm{x}}$ and $\varepsilon_{\mathrm{y}}$, respectively. The change of absorption introduced by formation of a complex may be represented by the term $\triangle A$, which is related to the total optical absorbancy $A$ by the relationship $\Delta A=A-\varepsilon_{\mathrm{x}} X-\varepsilon_{\mathrm{y}} Y$. The equilibrium concentration of the complex $Z$ is given by

$$
Z=\Delta A / \Delta \varepsilon
$$

where $\Delta \varepsilon=\varepsilon_{\mathrm{z}}-\varepsilon_{\mathrm{x}}-\varepsilon_{\mathrm{y}}$. The formation constant $K_{\mathrm{f}}$ is given by $K_{\mathrm{f}}=Z /[(X-Z)(Y-Z)]$ which on expansion becomes $Z / K_{\mathrm{f}}=X Y-Y Z-X Z+Z^{2}$. Assuming that $X Y \gg Z^{2}$ this becomes $Z / K_{\mathrm{f}}=X Y-Y Z-X Z$, or

$$
Z=X Y /\left(X+Y+1 / K_{\mathrm{f}}\right)
$$

On combining eq 1 and 2, the following is obtained 620

$$
\frac{X Y}{\Delta A}=\frac{1}{K_{\mathrm{f}} \Delta \varepsilon}+\frac{(X+Y)}{\Delta \varepsilon}
$$

Since $\Delta \varepsilon$ and $K_{\mathrm{f}}$ are constants, this equation represents a straight line when $[\mathrm{X}][\mathrm{Y}] / \Delta A$ is plotted against the sum of the stoichiometric concentrations $[\mathrm{X}]+[\mathrm{Y}]$.

\section{Measurements}

High performance liquid chromatograms were taken with a Tosoh SC-8010 chromatograph using the absorbance at $254 \mathrm{~nm}$ : a strong anion exchange column (TSKgel SAX), $40^{\circ} \mathrm{C}$; eluent, an aqueous solution of $0.2 \mathrm{M}$ sodium nitrate and $0.05 \mathrm{M}$ boric acid buffer $(\mathrm{pH}$ 9.7) with acetonitrile (1 vol\%).

${ }^{1} \mathrm{H}$ NMR spectra were recorded at $400 \mathrm{MHz}$ on a JNM-GX400 FT-NMR spectrometer at $27^{\circ} \mathrm{C}$. The samples for ${ }^{1} \mathrm{H}$ NMR spectra of a solution of $\mathrm{CyD}$ $\left(0.1 \mathrm{~mol} \mathrm{~L}^{-1}\right)$ and a solution containing $\mathrm{CyD}(0.1$ mol L $\left.{ }^{-1}\right)$ and carbon tetrachloride $\left(0.1 \mathrm{~mol} \mathrm{~L}^{-1}\right)$ were prepared in $1 \mathrm{wt} \% \mathrm{NaOD} / \mathrm{D}_{2} \mathrm{O}$. Those of a solution containing $\mathrm{CyD}\left(0.1 \mathrm{~mol} \mathrm{~L}^{-1}\right)$ and benzoate $(0.1 \mathrm{~mol}$ $\mathrm{L}^{-1}$ ) were prepared in $1 \mathrm{wt} \% \mathrm{NaOD} / \mathrm{D}_{2} \mathrm{O}$ using benzoic acid as benzoate. A two dimensional rotating frame Overhauser enhancement spectroscopy (2D ROESY) spectrum $^{11-13}$ was acquired in a sweep width of 2500 Hz. A spin-lock field was used during the mixing period of $1000 \mathrm{~ms}$ and $500 \mathrm{~ms}$ in order to minimize magnetization transfer through scalar couplings. Free induction decays which accumulated 128 times at each mixing time were stored in a matrix of $1024 \times 128$. The data matrix was expanded to $1024 \times 512$ by zero-filling for $F_{1}$-axis and multiplied by the sinebell window function prior to the double Fourier transform. Chemical shifts are given in parts per million (ppm) downfield from that of tetramethylsilane in chloroform- $d_{1}$ using internal capillary.

The absorption spectra were recorded using a Hitachi $\mathrm{U}-3300$ spectrophotometer at $25^{\circ} \mathrm{C}$.

\section{RESULTS AND DISCUSSION}

\section{Carboxylation of Benzoic Acid}

Figure 2 shows the dependence of the yield of terephthalic acid (para-carboxylated product) on the initial mole ratio of $\beta$-CyD to benzoic acid. The yield of terephthalic acid increases with $\beta$-CyD, and takes a maximum (39 mol\% with $100 \%$ selectivity) at a mole

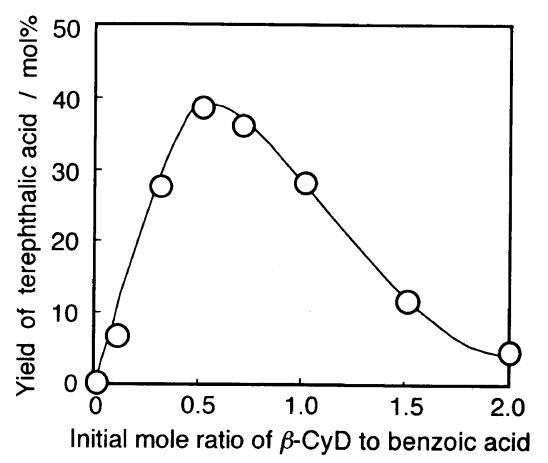

Figure 2. Plot of yield of terephthalic acid $v$ s. initial mole ratio of $\beta$-CyD to benzoic acid. Conditions: $30 \mathrm{~mL}$ of $30 \mathrm{wt} \% \mathrm{NaOH}$ aq, $3.0 \mathrm{mmol}$ of benzoic acid, $0.8 \mathrm{mmol}$ of copper powder, $9.5 \mathrm{mmol}$ of carbon tetrachloride, $60^{\circ} \mathrm{C}, 7 \mathrm{~h}$. 


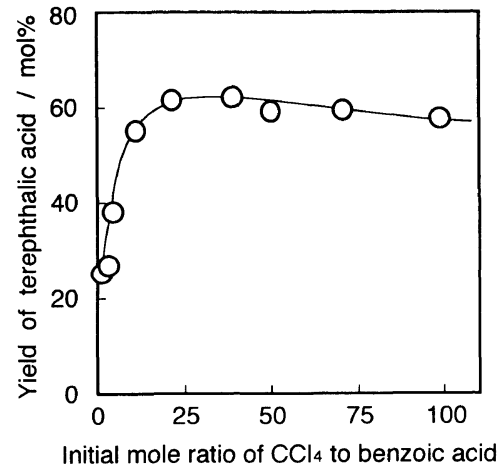

Figure 3. Plot of yield of terephthalic acid vs. initial mole ratio of carbon tetrachloride to benzoic acid. Conditions: $30 \mathrm{~mL}$ of $30 \mathrm{wt} \%$ $\mathrm{NaOH}$ aq, $3.0 \mathrm{mmol}$ of benzoic acid, $1.5 \mathrm{mmol}$ of $\beta$-CyD, $0.8 \mathrm{mmol}$ of copper powder, $60^{\circ} \mathrm{C}, 7 \mathrm{~h}$.

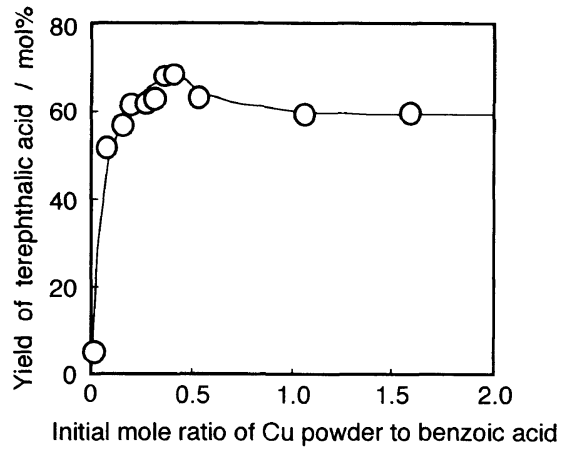

Figure 4. Plot of yield of terephthalic acid $v s$. initial mole ratio of copper powder to benzoic acid. Conditions: $30 \mathrm{~mL}$ of $30 \mathrm{wt} \% \mathrm{NaOH}$ aq, $3.0 \mathrm{mmol}$ of benzoic acid, $1.5 \mathrm{mmol}$ of $\beta$-CyD, $117 \mathrm{mmol}$ of carbon tetrachloride, $60^{\circ} \mathrm{C}, 7 \mathrm{~h}$.

ratio of $\beta$-CyD to benzoic acid of 0.5 , where the yields of phthalic acid (ortho-carboxylated product) and isophthalic acid (meta-carboxylated product) are 0.0 $\mathrm{mol} \%$ and $0.0 \mathrm{~mol} \%$, respectively. In the absence of $\beta$-CyD, however, carboxylation did not occur. The promotion of carboxylation by $\beta$-CyD is probably attributable to inclusion complex formation. The solubilities of carbon tetrachloride and benzoic acid in aqueous alkali in high concentration increase by the formation of the $\beta$-CyD-carbon tetrachloride complex and $\beta$-CyD-benzoic acid complex. Decrease in the yield of terephthalic acid at the initial mole ratios of $\beta$-CyD larger than 0.5 (see Figure 2) may be associated with the deactivation of the active species formed too much to react with the benzoic acid in the inclusion complex. When $\alpha$-CyD was used instead of $\beta$-CyD, the reaction did not proceed. The recovery of benzoic acid was $100 \mathrm{~mol} \%$. When $\gamma$-CyD was used instead of $\beta$-CyD, the yields of terephthalic acid, phthalic acid and isophthalic acid were $0.4 \mathrm{~mol} \%, 0.0 \mathrm{~mol} \%$, and $0.0 \mathrm{~mol} \%$, respectively.

Figure 3 exhibits the relationship between the yield of terephthalic acid and the initial amount of carbon tetrachloride at a mole ratio of $\beta-\mathrm{CyD}$ to benzoic acid of 0.5 . The yield of terephthalic acid has a maximal value $(63 \mathrm{~mol} \%)$ at a mole ratio of carbon tetrachloride to benzoic acid of 39. Carbon tetrachloride is required in large excess to get good yield of terephthalic acid, probably because a considerable part of the active species formed from carbon tetrachloride is decomposed by reaction with hydroxide ion from sodium hydroxide in

Polym. J., Vol. 28, No. 7, 1996

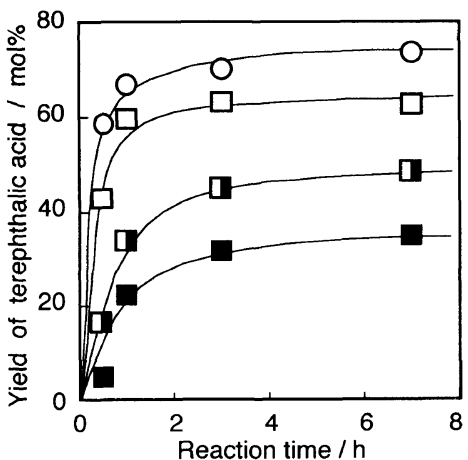

Figure 5. Plots of yields of terephthalic acid $v s$. reaction time in carboxylation in the presence of $p$-benzoquinone.: Initial mole ratios of $p$-benzoquinone to carbon tetrachloride $0.0(\bigcirc), 0.01(\square), 0.05$ (口), and 0.1 ( Conditions: $30 \mathrm{~mL}$ of $30 \mathrm{wt} \% \mathrm{NaOH}$ aq, $3.0 \mathrm{mmol}$ of benzoic acid, $1.2 \mathrm{mmol}$ of coppe powder, $2.1 \mathrm{mmol}$ of $\beta$-CyD, 117 mmol of carbon tetrachloride, $60^{\circ} \mathrm{C}$.

the aqueous solution.

Figure 4 depicts the dependence of the yield of terephthalic acid on the initial amount of copper powder at a mole ratio of carbon tetrachloride to benzoic acid of 39. The yield of terephthalic acid reaches a maximum ( $69 \mathrm{~mol} \%$ with $100 \%$ selectivity) at a mole ratio of copper powder to benzoic acid of 0.4 . The increase in the yield of terephthalic acid by the addition of a small amount of copper powder may be due to increase of the reaction surface area of copper powder.

The optimum amount of $\beta$-CyD was investigated under the following conditions: the initial mole ratio of carbon tetrachloride to benzoic acid of 39 and that of copper powder to benzoic acid of 0.4 . At an initial mole ratio of $\beta$-CyD to benzoic acid of 0.7 , the yield of terephthalic acid had a maximal value $(74 \mathrm{~mol} \%$ with $100 \%$ selectivity), where the yields of phthalic acid and isophthalic acid were $0.0 \mathrm{~mol} \%$ and $0.0 \mathrm{~mol} \%$, respectively. Recovery of benzoic acid was $23 \mathrm{~mol} \%$. In the previous communication, ${ }^{9}$ we reported that benzoic acid was converted to terephthalic acid in $75 \mathrm{~mol} \%$ yield with $87 \%$ selectivity by the use of carbon tetrachloride and copper powder in aqueous alkali with $\beta$-CyD as mediator. Shortly afterward, we examined the optimum amount of $\beta$-CyD, carbon tetrachloride and copper powder, respectively, on the carboxylation of benzoic acid by the use of $\beta$-CyD as mediator. The optimal conditions of high performance liquid chromatography for the product analysis were investigated to improve the separation of each peak. We found that the yield and selectivity of terephthalic acid were $74 \mathrm{~mol} \%$ and $100 \%$, respectively.

\section{Effects of Radical Inhibitors on the Carboxylation}

Figure 5 shows the relationship between the yield of terephthalic acid and reaction time on the addition of $p$-benzoquinone. The yield of terephtalic acid decreases remarkably with increasing $p$-benzoquinone, especially at the initial stage of the reaction. At a reaction time of $0.5 \mathrm{~h}$, the yield is $58 \mathrm{~mol} \%$ in the absence of $p$-benzoquinone, whereas it is only $4.7 \mathrm{~mol} \%$ at a mol ratio of p-benzoquinone to carbon tetrachloride of 0.1 . paraBenzoquinone is a strong radical-capturing agent. ${ }^{16}$ The decrease in the yield of terephthalic acid by the addition of $p$-benzoquinone should not be associated with the 


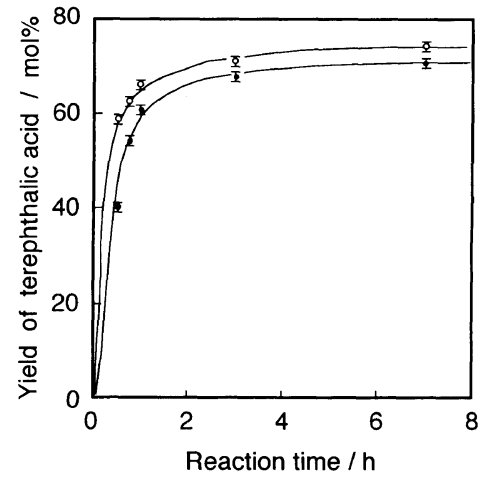

Figure 6. Plots of yields of terephthalic acid $v s$. reaction time under nitrogen $(\bigcirc)$ and oxygen (O). Conditions: $30 \mathrm{~mL}$ of $30 \mathrm{wt} \% \mathrm{NaOH}$ aq, $3.0 \mathrm{mmol}$ of benzoic acid, $1.2 \mathrm{mmol}$ of copper powder, $2.1 \mathrm{mmol}$ of $\beta$-CyD, $117 \mathrm{mmol}$ of carbon tetrachloride, $60^{\circ} \mathrm{C}$.

formation of $\beta$-CyD-p-benzoquinone complex, because the formation constant of $\beta$-CyD- $p$-benzoquinone complex is much smaller than that of $\beta$-CyD-benzoic acid complex as described later.

The dependence between the yield of terephthalic acid and reaction time under nitrogen $(O)$ and oxygen $(O)$ is shown in Figure 6. In this figure, the point and error bar shows the mean and range between the maximum and minimum of three observed values, respectively. The yield of terephtalic acid is $58 \mathrm{~mol} \%$ under nitrogen at the reaction time $0.5 \mathrm{~h}$, whereas it is $40 \mathrm{~mol} \%$ under oxygen. For all reaction times, the yields under oxygen are apparently smaller than those under nitrogen. According to the literature, ${ }^{17}$ oxygen exhibits significant retardation in the reactions involving trichloromethyl radical. Oxygen caused decrease of the yield of terephthalic acid in the present reaction, indicating the active species in the carboxylation to be a radical species, trichloromethyl radical.

Komiyama et $a l .{ }^{6}$ reported that the carboxylation of phenol with carbon tetrachloride and copper powder in aqueous alkali using $\beta$-CyD as a mediator probably proceeds with trichloromethyl cation as the active species, owing to the following: (1) Styrene, which strongly quenches the trichloromethyl radical, showed no measurable retardation in the carboxylation of phenol using $\beta$-CyD. (2) In the reaction under air, oxygen showed no measurable effect either on rate or selectivity. (3) Chloroform and hexachloroethane, produced in the reactions involving the trichloromethyl radical, were not formed at measurable rates in the reaction. The effect of oxygen in air on the carboxylation of phenol using $\beta$-CyD was estimated in the reaction under air at $1 \mathrm{~atm}$ at the reaction time $1 \mathrm{~h}$ by Komiyama et al. ${ }^{6}$

We investigated in detail the carboxylation of benzoic acid using $\beta$-CyD under air at $1 \mathrm{~atm}$. At a reaction time of $0.5 \mathrm{~h}$, the yield of terephthalic acid under air was $55 \mathrm{~mol} \%$, whereas the yields under nitrogen and oxygen were $58 \mathrm{~mol} \%$ and $40 \mathrm{~mol} \%$, respectively (see Figure 6). At a reaction time of $1 \mathrm{~h}$, the yield under air was 66 $\mathrm{mol} \%$, whereas the yield under nitrogen and oxygen were $67 \mathrm{~mol} \%$ and $60 \mathrm{~mol} \%$, respectively (see Figure 6). The decrease in yield under air was much smaller than that under oxygen. The solubility coefficient of oxygen in aqueous alkali is small (Bunsen coefficient: 0.01104 in $1.5 \mathrm{~mol} \mathrm{~L}^{-1}$ aqueous sodium hydroxide solution at

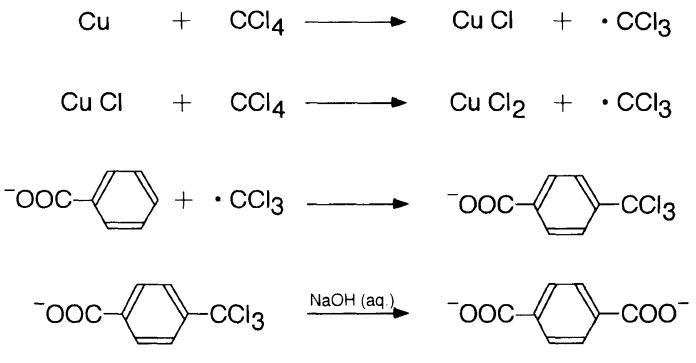

Scheme 2.

$\left.50^{\circ} \mathrm{C}\right) .^{18}$ The amount of dissolved oxygen in aqueous alkali under air at $1 \mathrm{~atm}$ was estimated using this coefficient: $0.00296 \mathrm{mmol}$. Thus, the amount of oxygen dissolved in the reaction mixture under air was very small compared to the amount of carbon tetrachloride $(117 \mathrm{mmol})$ added to the reaction mixture. This is probably the reason why Komiyama et al. ${ }^{6}$ could not find the small decrease in yield under air at a reaction time of $1 \mathrm{~h}$.

The paper by Komiyama et $a .^{6}$ describes that the trichloromethyl cation might be formed on the surface of copper powder with catalysis by copper powder. If the copper powder is a catalyst, the copper powder might remain unchanged at the end of reaction. However, remaining copper powder was not found at all in the reaction even at reaction time $1 \mathrm{~h}$. No solid matter could be found in the reaction mixture. The color of the reaction mixture was deep dark brown due to the formation of the $\beta$-CyD carbon tetrachloride complex. At a small amount of $\beta-\mathrm{CyD}$, however, light blue coloration was identified in the reaction mixture, ascribed to copper(II) ions. Consequently, copper powder is evidently not a catalyst, but a reactant with carbon tetrachloride to form an active species, trichloromethyl radical, as shown in Scheme 2. In the reaction of organotin compounds with carbon tetrachloride in the presence of copper power, the reaction of copper powder with carbon tetrachloride produced copper(I) chloride. ${ }^{19}$ Copper(I) chloride and carbon tetrachloride formed copper(II) chloride and the trichloromethyl radical in the reaction of carbon tetrachloride with amines. ${ }^{20}$ In a preliminarily study, we confirmed that copper(I) chloride is also effective for the reaction in the place of the copper powder. The reaction of benzoic acid with carbon tetrachloride and copper(I) chloride using $\beta$-CyD as mediator produced terephthalic acid in $43 \mathrm{~mol} \%$ yield, under the following conditions: $30 \mathrm{~mL}$ of $30 \mathrm{wt} \% \mathrm{NaOH}$ aq, $0.54 \mathrm{mmol}$ of copper(I) chloride, $3.0 \mathrm{mmol}$ of benzoic acid, $1.5 \mathrm{mmol}$ of $\beta$-CyD, and $151 \mathrm{mmol}$ of carbon tetrachloride, at $60^{\circ} \mathrm{C}$, for $7 \mathrm{~h}$. Consequently, the active species formed from carbon tetrachloride and copper powder should be the trichloromethyl radical, not the trichloromethyl cation, as shown in Scheme 2. The trichloromethyl radical predominantly attacks at the para position of benzoic acid. The resulting $p$-trichloromethyl benzoate is hydrolyzed to give terephthalate, as shown in Scheme 2.

\section{Inclusion-Complex Formation of $\beta-C y D$ with Benzoate Anion and $\beta-C y D$ with p-Benzoquinone}

For determination of the formation constants of 
Table I. Formation constants $\left(K_{\mathrm{f}}\right)$, differences in molar extinction coefficients for free and complexed substrate $(\Delta \varepsilon)$, and wavelengths of $\beta$-CyD complexes in aqueous solution at $25^{\circ} \mathrm{C}$

\begin{tabular}{cccc}
\hline Guest & $K_{\mathrm{f}} / \mathbf{M}^{-1 \mathrm{c}}$ & $\Delta \varepsilon / \mathrm{M}^{-1} \mathrm{~cm}^{-1}$ & Wavelength/nm \\
\hline Benzoate anion $^{\mathrm{a}}$ & $422 \pm 10$ & $212 \pm 13$ & 275,280 \\
-Benzoquinone $^{\mathrm{b}}$ & $35 \pm 2.0$ & $2692 \pm 119$ & 246,252
\end{tabular}

${ }^{\text {a }}$ Benzoic acid $\left(0.26 \mathrm{mmol} \mathrm{L}^{-1}\right)$ and $\beta$-CyD $(0,2.5,5.0,7.5,10 \mathrm{mmol}$ $\left.\mathrm{L}^{-1}\right)$ in aqueous solution. ${ }^{\mathrm{b}}$ Para-benzoquinone $\left(0.13 \mathrm{mmol} \mathrm{L}^{-1}\right)$ and $\beta$-CyD $\left(0,2.0,4.0,7.0,8.0 \mathrm{mmol} \mathrm{L}^{-1}\right)$ in aqueous solution. ' The reported formation constant is the average of two determinations agreeing within $10 \%$.

Table II. Proton chemical shifts of $\beta$-CyD in the absence $\left(\delta_{0}\right)$ and presence $(\delta)$ of carbon tetrachloride ${ }^{\mathrm{a}}$

\begin{tabular}{cccc}
\hline Protons of $\beta$-CyD & $\delta_{0} / \mathrm{ppm}^{\mathrm{b}}$ & $\delta / \mathrm{ppm}^{\mathrm{c}}$ & $\delta-\delta_{0} / \mathrm{ppm}^{\mathrm{d}}$ \\
\hline H-1 & 4.95 & 4.94 & -0.01 \\
H-2 & 3.51 & 3.50 & -0.01 \\
H-3 & 3.88 & 3.80 & -0.08 \\
H-4 & 3.45 & 3.45 & 0.00 \\
H-5 & 3.82 & 3.84 & +0.02 \\
H-6a & 3.84 & 3.86 & +0.02 \\
H-6b & 3.78 & 3.80 & +0.02 \\
\hline
\end{tabular}

${ }^{\text {a }}$ Conditions: $400 \mathrm{MHz}^{1} \mathrm{H}$ NMR at $27^{\circ} \mathrm{C} . \quad{ }^{\mathrm{b}} \beta$-CyD $\left(0.1 \mathrm{~mol} \mathrm{~L}^{-1}\right)$ in $1 \mathrm{wt} \% \mathrm{NaOD} / \mathrm{D}_{2} \mathrm{O}$ solution. ${ }^{\mathrm{c}} \beta-\mathrm{CyD}\left(0.1 \mathrm{~mol} \mathrm{~L}^{-1}\right)$ and carbon tetrachloride $\left(0.1 \mathrm{~mol} \mathrm{~L}^{-1}\right)$ in $1 \mathrm{wt} \% \mathrm{NaOD} / \mathrm{D}_{2} \mathrm{O}$ solution. ${ }^{\mathrm{d}}$ Signs + and - indicate downfield and upfield shifts, respectively.

$\beta$-CyD-benzoate anion inclusion complex and $\beta$-CyD$p$-benzoquinone inclusion complex, absorption spectra were measured at $25^{\circ} \mathrm{C}$. The benzoic acid molecule was converted to the benzoate anion in aqueous solution ( $\mathrm{pH} 7)$. Change in absorbance of benzoate anion $(0.26$ mmol $\mathrm{L}^{-1}$ ) was determined as a function of $\beta$-CyD concentration $\left(2.5-10 \mathrm{mmol} \mathrm{L}^{-1}\right)$. That of $p$-benzoquinone $\left(0.13 \mathrm{mmol} \mathrm{L}^{-1}\right)$ was measured as a function of $\beta$-CyD concentration $\left(2.0-8.0 \mathrm{mmol} \mathrm{L}^{-1}\right)$. Formation constants were determined by the Benesi-Hildebrand method. ${ }^{14,15}$ In the absorption spectra of the benzoate anion at different $\beta$-CyD concentrations, the isosbestic point was observed at $258 \mathrm{~nm}$. In those of $p$-benzoquinone at different $\beta$-CyD concentrations, isosbestic points were observed at 232 and $258 \mathrm{~nm}$. These isosbestic points indicated a $1: 1$ equilibrium. As shown in Table I, the formation constants $\left(K_{\mathrm{f}}\right)$, the difference of the molar extinction coefficients for free and complexed substrate $(\Delta \varepsilon)$, and the monitored wavelength of $\beta$-CyD inclusion complexes are summarized. The value for the formation constant of $\beta$-CyD-benzoate anion is $422 \pm$ $10 \mathrm{M}^{-1}$, which is in good agreement with the literature value $\left(372 \pm 45 \mathrm{M}^{-1}\right.$ in phosphate buffer solution $(\mathrm{pH}$ 6.2)). ${ }^{21}$ The formation constant of $\beta$-CyD $-p$-benzoquinone is $35 \pm 2.0 \mathrm{M}^{-1}$ and is far smaller than that of the $\beta$-CyD-benzoate anion.

Inclusion-Complex Formation of Cyclodextrins with Carbon Tetrachloride in Alkaline Aqueous Solution

The $400 \mathrm{MHz}{ }^{1} \mathrm{H}$ NMR spectrum of a solution containing $\beta$-CyD $\left(0.1 \mathrm{moLl}^{-1}\right)$ and carbon tetrachloride $\left(0.1 \mathrm{~mol} \mathrm{~L}^{-1}\right)$ was compared with that of a solution of $\beta$-CyD $\left(0.1 \mathrm{~mol} \mathrm{~L}^{-1}\right)$. Table II shows the values of ${ }^{1} \mathrm{H}$ chemical shifts of $\beta$-CyD in the absence of carbon tetrachloride and presence of carbon tetrachloride. The C- $1-\mathrm{C}-6$ protons in the glucose unit of $\beta-\mathrm{CyD}$ are defined as $\mathrm{H}-1-\mathrm{H}-6$, respectively, as shown in Figure 1. According to the literature, ${ }^{22} \mathrm{H}-3$ and $\mathrm{H}-5$ atoms are directed toward the interior of the cavity of $\beta$-CyD, whereas $\mathrm{H}-1, \mathrm{H}-2$, and $\mathrm{H}-4$ atoms are located on the exterior. The shifts of the $\mathrm{H}-3(-0.08)$ and $\mathrm{H}-5(+0.02)$ atoms located in the interior of the cavity of $\beta$-CyD are larger than those of $\mathrm{H}-1(-0.01), \mathrm{H}-2(-0.01)$, and $\mathrm{H}-4$ $(0.00)$ atoms located on the outer surface of $\beta-C y D$. The upfield shift of the H-3 atom and downfield shift of the $\mathrm{H}-5$ atom are due to the magnetic anisotropy effect of the $\mathrm{C}-\mathrm{Cl}$ bonds. ${ }^{23,24}$ These facts suggest that carbon tetrachloride may thus be included in the cavity of $\beta$ CyD. When $\alpha$-CyD was used instead of $\beta$-CyD, $\alpha-\mathrm{CyD}$ formed a white precipitate with carbon tetrachloride. When $\gamma$-CyD was used instead of $\beta$-CyD, carbon tetrachloride hardly dissolved in solution. The filtrates of these mixtures of $\alpha-\mathrm{CyD}$ and $\gamma-\mathrm{CyD}$, respectively, were analyzed by ${ }^{1} \mathrm{H}$ NMR. The values of ${ }^{1} \mathrm{H}$ chemical shifts were observed not to change from those in the absence of carbon tetrachloride.

Sanemasa et al. ${ }^{25}$ reported the formation constants of $\mathrm{CyD}$-carbon tetrachloride complexes determined by the volatilization rate of a guest from the aqueous phase into the gaseous phase. The formation constant $\left(42 \pm 17 \mathrm{M}^{-1}\right)$ of the $\alpha-\mathrm{CyD}$-carbon tetrachloride complex was much smaller than that $\left(150 \pm 35 \mathrm{M}^{-1}\right)$ of the $\beta$-CyD-carbon tetrachloride complex. The white precipitate in solution containing $\alpha-\mathrm{CyD}$ and carbon tetrachloride as described above, should be associated with the complex formation of $\alpha-\mathrm{CyD}$-carbon tetrachloride. The carbon tetrachloride molecule is partially included in $\alpha-\mathrm{CyD}$ due to the size limitation of $\alpha-\mathrm{CyD}$, according to the literature. ${ }^{25}$ Precipitation seemed to occur through decrease in the solubility of $\alpha$-CyD caused by including carbon tetrachloride partially. The association between $\gamma$-CyD and carbon tetrachloride has not been observed, according to the literature. ${ }^{25}$ The association between $\gamma$-CyD and carbon tetrachloride was also not perceived by our measurement of ${ }^{1} \mathrm{H}$ chemical shifts of $\gamma$-CyD as described above. Calorimetric studies of CyD complexes with benzoic acid using a microcalorimeter by Siimer et al. ${ }^{26}$ revealed that benzoic acid formed unstable inclusion complex with $\gamma$-CyD. Thus, the carboxylation of benzoic acid by using $\gamma$-CyD hardly proceeded.

\section{Conformation of Cyclodextrin-Benzoate Inclusion Com- plexes in Alkaline Aqueous Solution}

In the previous communication, ${ }^{10}$ the conformation of $\beta$-CyD-benzoate inclusion complex in aqueous solution was determined by measurement of the ${ }^{1} \mathrm{H}$ chemical shifts of $\beta$-CyD and the ROESY spectrum on the aqueous alkaline solution of $\beta-\mathrm{CyD}$ and benzoic acid. The $400 \mathrm{MHz}{ }^{1} \mathrm{H}$ NMR spectrum of a solution containing $\beta$-CyD $\left(0.1 \mathrm{~mol} \mathrm{~L}^{-1}\right)$ and benzoate $\left(0.1 \mathrm{~mol} \mathrm{~L}^{-1}\right)$ was compared with that of a solution of $\beta$-CyD $(0.1$ mol $\left.\mathrm{L}^{-1}\right)$. The benzoic acid molecule was converted to the benzoate anion in aqueous alkaline solution. Table III shows the values of ${ }^{1} \mathrm{H}$ chemical shifts of $\beta$-CyD in the absence of benzoate anion and the presence of benzoate anion. In the presence of benzoate anion, all 
Table III. Proton chemical shifts of $\beta$-CyD in the absence $\left(\delta_{0}\right)$ and presence $(\delta)$ of benzoate anion ${ }^{\mathrm{a}}$

\begin{tabular}{cccc}
\hline Protons of $\beta$-CyD & $\delta_{0} / \mathrm{ppm}^{\mathrm{b}}$ & $\delta / \mathrm{ppm}^{\mathrm{c}}$ & $\delta-\delta_{0} / \mathrm{ppm}^{\mathrm{d}}$ \\
\hline H-1 & 4.93 & 4.92 & -0.01 \\
H-2 & 3.49 & 3.49 & 0.00 \\
H-3 & 3.86 & 3.83 & -0.03 \\
H-4 & 3.42 & 3.41 & -0.01 \\
H-5 & 3.77 & 3.71 & -0.06 \\
H-6 & 3.81 & 3.78 & -0.03 \\
\hline
\end{tabular}

${ }^{a}$ Conditions: $400 \mathrm{MHz}^{1} \mathrm{H}$ NMR at $27^{\circ} \mathrm{C} . \quad{ }^{\mathrm{b}} \beta$-CyD $\left(0.1 \mathrm{~mol} \mathrm{~L}^{-1}\right)$ in $1 \mathrm{wt} \% \mathrm{NaOD} / \mathrm{D}_{2} \mathrm{O}$ solution. ${ }^{\mathrm{c}} \beta-\mathrm{CyD}\left(0.1 \mathrm{~mol} \mathrm{~L}^{-1}\right)$ and benzoate anion $\left(0.1 \mathrm{~mol} \mathrm{~L}^{-1}\right)$ in $1 \mathrm{wt} \% \mathrm{NaOD} / \mathrm{D}_{2} \mathrm{O}$ solution. ${ }^{\mathrm{d}} \mathrm{Sign}$ - indicates upfield shifts.

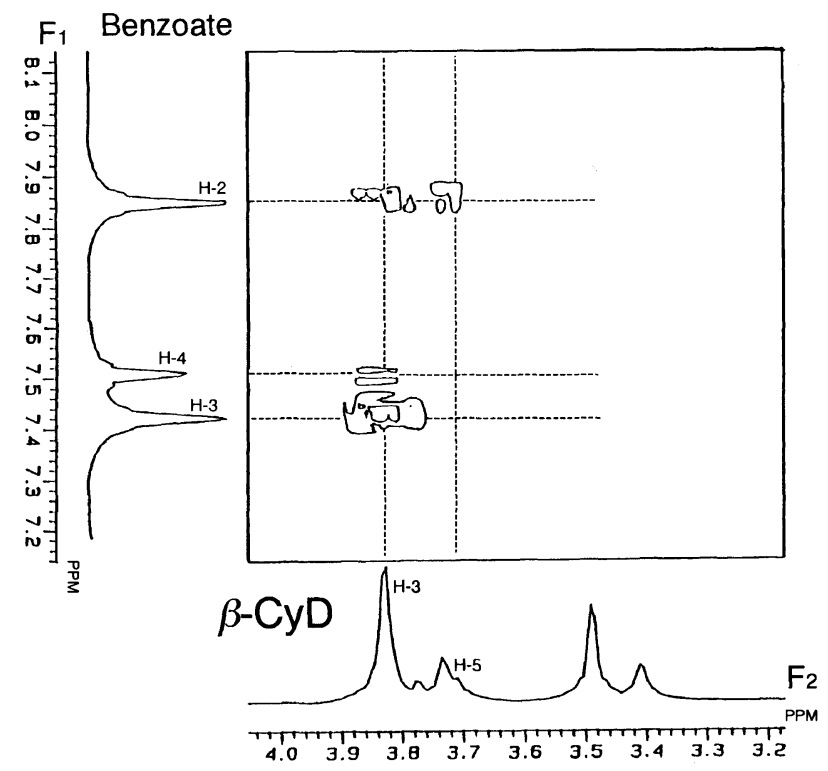

Figure 7. 2D-ROESY spectrum of a solution containing $\beta-\mathrm{CyD}$ $\left(0.1 \mathrm{~mol} \mathrm{~L}^{-1}\right)$ and benzoate anion $\left(0.1 \mathrm{~mol} \mathrm{~L}^{-1}\right)$ in $1 \mathrm{wt} \% \mathrm{NaOD} / \mathrm{D}_{2} \mathrm{O}$ at $27^{\circ} \mathrm{C}$. Projection spectra on the $F_{1}$-axis and $F_{2}$-axis, respectively, were obtained from the $J$-resolved $2 \mathrm{D}$ spectrum.

protons of $\beta$-CyD shifted upfield. The larger changes in the chemical shifts of $\mathrm{H}-3(-0.03)$ and $\mathrm{H}-5(-0.06)$, compared with those of $\mathrm{H}-1(-0.01), \mathrm{H}-2(0.00)$, and $\mathrm{H}-4(-0.01)$, indicate that the benzoate anion is included in the cavity of the $\beta$-CyD molecule. The upfield shifts are due to the magnetic anisotropy effect of the phenyl group of benzoate.

Figure 7 exhibits the ROESY spectrum of the solution containing $\beta$-CyD and benzoate anion, where the $J$ resolved spectrum of benzoate is shown on the $F_{1}$-axis and that of $\beta$-CyD on the $F_{2}$-axis. The cross-peak connecting the $\mathrm{H}-3$ resonance of $\beta-\mathrm{CyD}$ to the $\mathrm{H}-3$ resonance of benzoate is remarkably observed, and that to the $\mathrm{H}-2$ and $\mathrm{H}-4$ resonances of benzoate is observable. The cross-peak connecting the $\mathrm{H}-5$ resonance of $\beta$ $\mathrm{CyD}$ to the $\mathrm{H}-2$ resonance of benzoate is appreciable. These results indicate that the $\mathrm{H}-2$ atom of benzoate is situated near the $\mathrm{H}-5$ atom of $\beta-\mathrm{CyD}$ and the $\mathrm{H}-3$ atom of benzoate lies close to the $\mathrm{H}-3$ atom of $\beta$-CyD. Thus, the conformation of $\beta$-CyD-benzoate inclusion complex in aqueous alkali can be proposed, as shown in Figure 9. In this figure, $\beta$-CyD is illustrated simply by its cavity; the inner diameter of cavity $6.0 \AA$ for the primary hydroxyl side, $6.4 \AA$ for the secondary hydroxyl

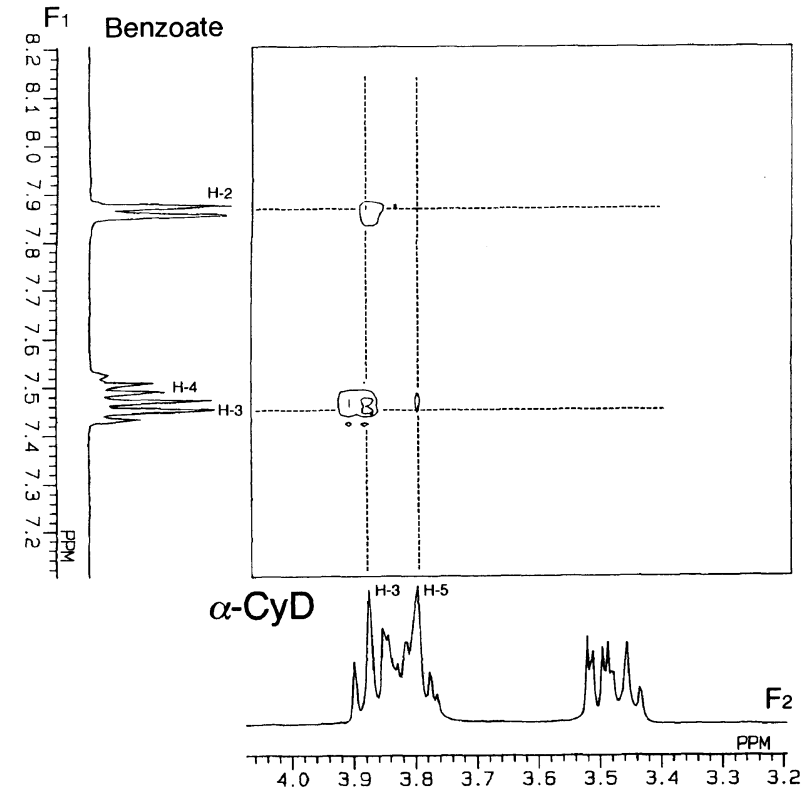

Figure 8. 2D-ROESY spectrum of a solution containing $\alpha$-CyD $\left(0.1 \mathrm{~mol} \mathrm{~L}^{-1}\right)$ and benzoate anion $\left(0.1 \mathrm{~mol} \mathrm{~L}^{-1}\right)$ in $1 \mathrm{wt} \% \mathrm{NaOD} / \mathrm{D}_{2} \mathrm{O}$ at $27^{\circ} \mathrm{C}$. Projection spectra on the $F_{1}$-axis and $F_{2}$-axis, respectively, were obtained from the $J$-resolved $2 \mathrm{D}$ spectrum.

side, and the depth of the cavity is $7.9 \AA$, according to the literature. ${ }^{27}$ The benzoate anion is axially included in the cavity of $\beta$-CyD with orientation such that the carboxylate group is at the primary hydroxyl side of $\beta$ CyD and the para position of benzoate, at the secondary hydroxyl side of $\beta$-CyD.

The conformation of $\alpha$-CyD-benzoate inclusion complex in aqueous alkali was determined by a similar method. Figure 8 illustrates the ROESY spectrum of the solution containing $\alpha-\mathrm{CyD}$ and benzoate anion. The cross-peak connecting the $\mathrm{H}-3$ resonance of $\alpha-\mathrm{CyD}$ to the $\mathrm{H}-3$ resonance of benzoate is clearly observed, and that to the $\mathrm{H}-2$ resonance of benzoate is observable. The cross-peak connecting the $\mathrm{H}-5$ resonance of $\alpha-\mathrm{CyD}$ to the $\mathrm{H}-3$ resonance of benzoate is appreciable. These results indicate that the $\mathrm{H}-2$ atom of benzoate lies close to the $\mathrm{H}-3$ atom of $\alpha-\mathrm{CyD}$ and the $\mathrm{H}-3$ atom of benzoate is located between the H-3 and H-5 atoms of $\alpha-\mathrm{CyD}$. Figure 9 depicts the proposed conformation of $\alpha-\mathrm{CyD}$ benzoate inclusion complex in aqueous alkali. In this figure, $\alpha$-CyD is illustrated simply by its cavity: the inner diameter of cavity $4.7 \AA$ for the primary hydroxyl side, $5.2 \AA$ for the secondary hydroxyl side, and the depth of the cavity is $7.9 \AA$, according to the literature. ${ }^{27}$ The benzoate anion is axially included in the cavity of $\alpha-\mathrm{CyD}$ with an orientation which directs the para position of benzoate to the primary hydroxyl side of $\alpha-\mathrm{CyD}$ and the carboxylate group to the secondary hydroxyl side of $\alpha$-CyD.

Thermochemical investigation of $\beta$-CyD complexes with benzoic acid and sodium benzoate using a microcalorimeter by Siimer et $\mathrm{al}^{28}$ reveals that the carboxyl group and carboxylate ion enters the cavity of $\beta$-CyD first, but does not determine the orientation direction of the guest molecule in the cavity of $\beta$-CyD. The NMR spectroscopy by Bergeron et al. ${ }^{29}$ indicates that both benzoic acid and sodium benzoate penetrate the cavity of $\alpha-\mathrm{CyD}$ at the secondary hydroxyl side, carboxyl 
group first, although the sodium benzoate penetration was more random. However, ${ }^{1} \mathrm{H}-{ }^{1} \mathrm{H}$ intermolecular nuclear Overhauser effect (NOE) between $\alpha$-CyD and sodium benzoate is not observed in the literature, ${ }^{29}$ owing to the weak binding of sodium benzoate in the cavity of $\alpha$-CyD. The ROESY ${ }^{1-13}$ method is useful for NOE measurement of moderately large molecules (molecular weight of about 1000). We succeeded in the determination of the conformations of $\beta$-CyD-benzoate inclusion complex and $\alpha$-CyD-benzoate inclusion complex by the ROESY method. From our measurement of formation constant of $\beta$-CyD-benzoate as described above, the $79 \%$ of benzoate anions in the solution form inclusion complexes with $\beta$-CyD. The benzoate anion included in the cavity of $\beta$-CyD, as shown in Figure 9, can be attacked at the 4-position selectively by the active species. The proposed conformation of $\beta-\mathrm{CyD}$ benzoate inclusion complex is consistent with the positional selectivity of the carboxylation of benzoic acid. The proposed conformation of $\alpha$-CyD-benzoate inclusion complex is compatible with the finding that carboxylation did not occur.
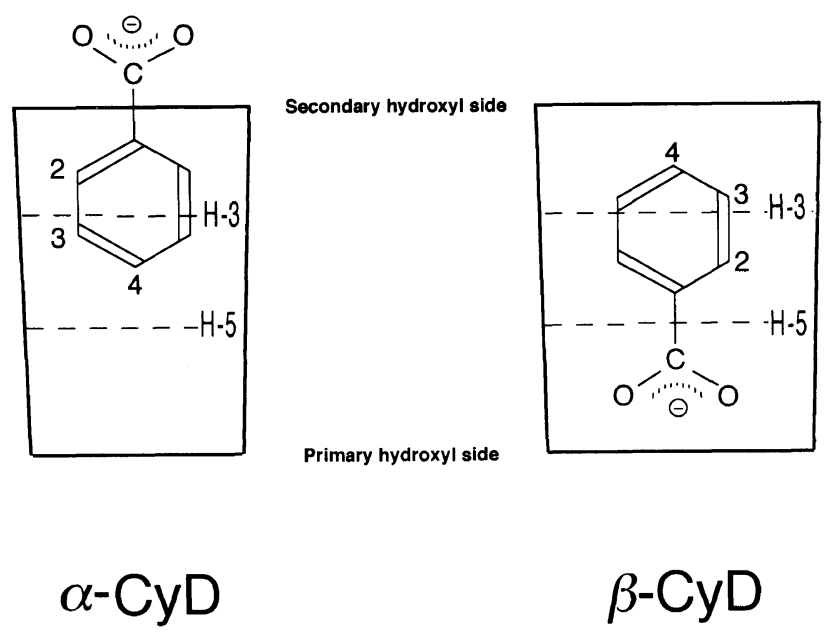

Figure 9. Proposed conformations of the $\alpha-\mathrm{CyD}$-benzoate inclusion complex and the $\beta$-CyD-benzoate inclusion complex; -----H-3 and - - - - H-5 show planes comprised of the corresponding atoms of $\alpha-\mathrm{CyD}$ and $\beta$-CyD, respectively.

\section{Mechanism of Selective Carboxylation}

The solubility of carbon tetrachloride in water is poor $\left(0.024 \mathrm{wt} \%\right.$ at $\left.50{ }^{\circ} \mathrm{C}\right) .{ }^{30}$ Therefore, carbon tetrachloride itself may be little concerned with the reaction in aqueous alkali. When carbon tetrachloride is included in the cavity of the $\beta$-CyD, it can be soluble in aqueous alkali and concerned with the reaction. The carbon tetrachloride included in $\beta$-CyD may react with metallic copper powder, generating copper(I) chloride and the trichloromethyl radical, as shown in Scheme 2. Copper(I) chloride may also transfer an electron to carbon tetrachloride leading to formation of the trichloromethyl radical and copper(II) chloride.

The proposed mechanism of the selective synthesis of terephthalic acid using $\beta-\mathrm{CyD}$ as mediator is shown in Figure 10 . The benzoate anion is axially included in the cavity of $\beta-C y D$ with an orientation such that the carboxylate group is at the primary hydroxyl side of $\beta$-CyD and the para position of benzoate, at the secondary hydroxyl side of $\beta$-CyD. Carbon tetrachloride included in $\beta$-CyD with copper powder forms the trichloromethyl radical, as the active species. The trichloromethyl radical should attack predominantly at the para position of the benzoate anion included in $\beta$-CyD. The $p$-trichloromethyl benzoate is rapidly hydrolyzed to give terephthalate in aqueous alkali.

The benzoate anion is axially included in the cavity of $\alpha-\mathrm{CyD}$ with orientation which directs the para position of benzoate to the primary hydroxyl side of $\alpha-\mathrm{CyD}$, as shown in Figure 9. The primary hydroxyl group of $\alpha$ CyD has considerable freedom of movement about the C-5-C-6 bond. ${ }^{3}$ The inner diameter of primary hydroxyl side of $\alpha$-CyD $(4.7 \AA)^{27}$ is smaller than that of the secondary side $(5.2 \AA) .{ }^{27}$ The trichloromethyl radical may not attack at the benzoate anion included in $\alpha-\mathrm{CyD}$ from primary hydroxyl side due to steric hindrance of the C-5-C-6 bond. According to the literature, ${ }^{25}$ the carbon tetrachloride molecule is partially included in $\alpha-\mathrm{CyD}$. The white precipitate in the solution containing $\alpha-\mathrm{CyD}$ and carbon tetrachloride as described above, may be due to the decrease in the solubility of $\alpha-\mathrm{CyD}$ caused by including carbon tetrachloride partially. Thus, carbon tetrachloride in the aqueous alkaline solution of $\alpha-\mathrm{CyD}$ could hardly form the trichloromethyl

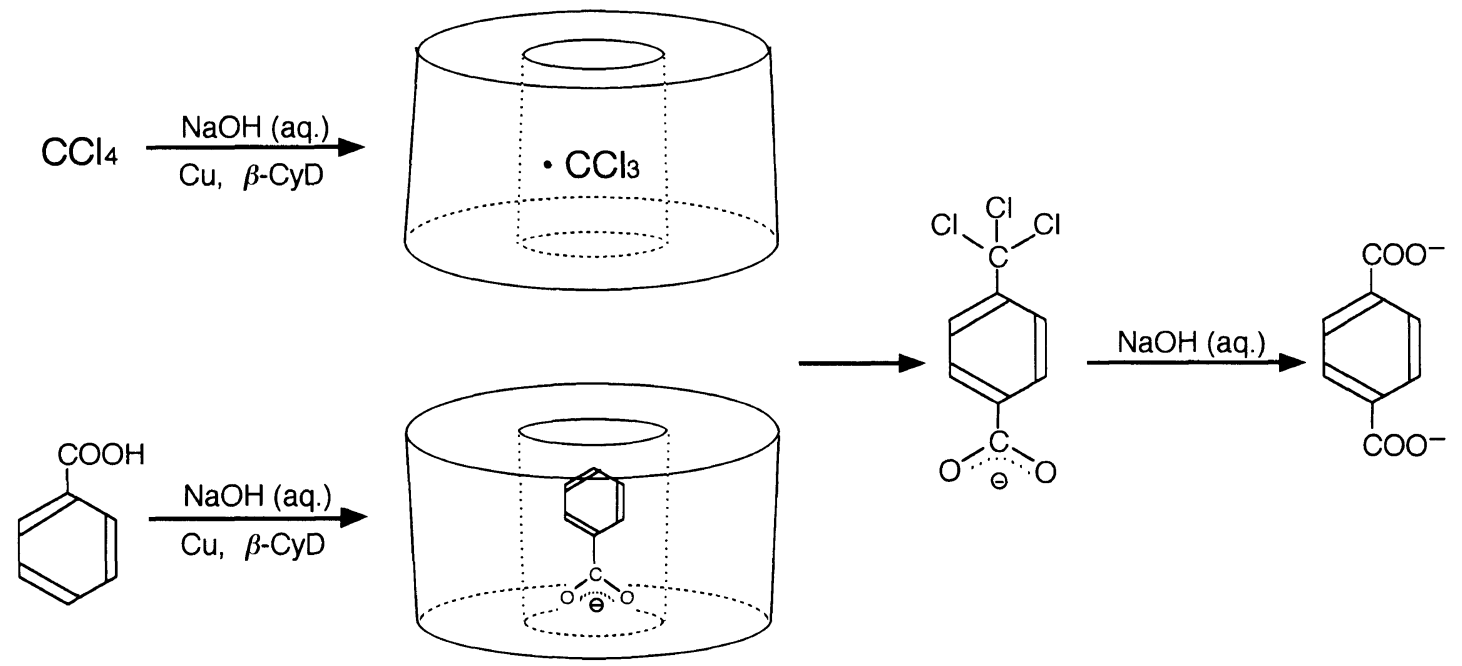

Figure 10. Proposed mechanism of carboxylation of benzoic acid using $\beta$-CyD as mediator. 
radical, as the active species. Based on the interaction between $\gamma$-CyD and carbon tetrachloride, carbon tetrachloride hardly dissolves in solution. Consequently, carboxylation hardly proceedes by $\alpha-\mathrm{CyD}$ or $\gamma-\mathrm{CyD}$.

\section{CONCLUSIONS}

The selective carboxylation of benzoic acid with carbon tetrachloride, copper powder and aqueous alkali was achieved by the use of $\beta-\mathrm{CyD}$ as mediator at $60^{\circ} \mathrm{C}$ under nitrogen of atmospheric pressure, producing terephthalic acid in $74 \mathrm{~mol} \%$ yield with $100 \%$ selectivity. The carboxylation probably proceeds with the trichloromethyl radical formed from carbon tetrachloride and copper powder, as the active species. The benzoate anion is axially included in the cavity of $\beta$-CyD with orientation such that the carboxylate group is at the primary hydroxyl side of $\beta$-CyD and the para position of benzoate, at the secondary hydroxyl side of $\beta$-CyD. The benzoate anion included in $\beta$-CyD is predominantly attacked at the para position by the trichloromethyl radical and forms terephthalic acid with very high selectivity. The conformation of $\beta$-CyD-benzoate inclusion complex is consistent with the positional selectivity of the reaction.

\section{REFERENCES}

1. A. Saffer and R. S. Barker, U.S. Patent 3069462 (1962); Chem. Abstr., 58, 10129b (1963).

2. B. Raecke, W. Stein, and H. Schirp, U.S. Patent 2794830 (1957); Chem. Abstr., 51, 16549i (1957).

3. M. L. Bender and M. Komiyama, "Cyclodextrin Chemistry," Springer-Verlag, Berlin, Heidelberg, New York, N.Y., 1978.

4. H. Hirai, Kagaku to Kyoiku (Chemistry and Education), 38, 158 (1990).
5. K. Reimer and F. Tiemann, Ber. Dtsch. Chem. Ges., 9, 1285 (1876).

6. M. Komiyama and H. Hirai, J. Am. Chem. Soc., 106, 174 (1984)

7. R. T. Morrison and R. N. Boyd, "Organic Chemistry," 4th ed, Allyn and Bacon, Inc., Boston, 1983.

8. H. Wynberg, Chem. Rev., 60, 169 (1960).

9. H. Hirai and H. Mihori, Chem. Lett., 1523 (1992).

10. H. Hirai, Y. Shiraishi, H. Mihori, K. Saito, and T. Kawamura, Polym. J., 28, 91 (1996).

11. A. A. Bothner-By, R. L. Stephens, J. Lee, C. D. Warren, and R. W. Jeanloz, J. Am. Chem. Soc., 106, 811 (1984).

12. A. Bax and D. G. Davis, J. Magn. Reson., 63, 207 (1985).

13. W. Saka, Y. Yamamoto, Y. Inoue, R. Chûjô, K. Takahashi, and K. Hattori, Bull. Chem. Soc. Jpn., 63, 3175 (1990).

14. H. A. Benesi and J. H. Hildebrand, J. Am. Chem. Soc., 71, 2703 (1949).

15. R. L. VanEtten, J. F. Sebastian, G. A. Clowes, and M. L. Bender, J. Am. Chem. Soc., 89, 3242 (1967).

16. J. C. Bevington, N. A. Ghanem, and H. W. Melville, Trans. Faraday Soc., 51, 946 (1955).

17. W. J. Lautenberger, E. N. Jones, and J. G. Miller, J. Am. Chem. Soc., 90, 1110 (1968).

18. R. Battino, "Solubility Data Series," Vol. 7, Pergamon Press, Oxford, 1981.

19. G. A. Razuvaev, O. S. D'yachkovskaya, and V. I. Fionov, Dokal. Chem., 177, 1173 (1967).

20. M. Asscher and D. Vofsi, J. Chem. Soc., 2261 (1961).

21. M. Kamiya, S. Mitsuhashi, M. Makino, and H. Yoshioka, J. Phys. Chem., 96, 95 (1992)

22. P. V. Demarco and A. L. Thakkar, Chem. Commun., 2 (1970).

23. H. M. McConnell, J. Chem. Phys., 27, 226 (1957)

24. G. S. Reddy and J. H. Goldstein, J. Chem. Phys., 38, 2736 (1963).

25. M. Nishimura, T. Deguchi, and I. Sanemasa, Bull. Chem. Soc. Jpn., 62, 3718 (1989).

26. E. Siimer and M. Kurvits, Thermochim. Acta, 140, 161 (1989).

27. W. Saenger, Angew. Chem., Int. Ed. Engl., 19, 344 (1980)

28. E. Siimer, M. Kurvits, and A. Köstner, Thermochim. Acta, 116, 249 (1987).

29. R. J. Bergeron, M. A. Channing, and K. A. McGovern, J. Am. Chem. Soc., 100, 2878 (1978).

30. H. Stephen and T. Stephen, "Solubilities of Inorganic and Organic Compounds," Vol. 1, Pergamon Press, Oxford, 1963. 